\title{
Implementation of Bologna Process in Albania (2007 -2015)
}

\author{
Rovena Sulstarova \\ Doctorate Student, \\ Department of Psychology and Pedagogy, \\ University of Tirana, Albania
}

Doi: $10.2478 / \mathrm{mjss}-2018-0096$

\begin{abstract}
After signing the Bologna Declaration, Albania started the Bologna reforms in 2004. During the last 8 years higher education institutions in Albania has undergone a series reforms and new changes are under the way with the new law on higher education that is being discussed currently. However there is still a long way to go when it comes to practical implementation of Bologna principles and the related policy line. The aim of this paper is to investigate the process of harmonization of the Albanian Higher Education with the standards and practices of other EU member states, by focusing on the strategies and policies adopted by the state, institutions of higher education and by other actors involved. Despite the political rhetoric, the higher education system in Albania has displayed many problems with respect to the Bologna Process, having to do with the implementation of the structural reforms of Bologna context, enhancement of students' learning, their mobility and the orientation of the higher education towards the business and the work market etc.
\end{abstract}

Keywords: Higher Education in Albania, Bologna Process, institutions of higher education, reforms.

\section{Introduction}

Albanian higher education sector has tried to mimic the developments of EU countries which have undergone reform processes based on several European conventions and communiqués: Sorbonne (1998), Bologna (1999), Prague (2001), Berlin (2003), Bergen (2005) and London (2007). This Europeanization process has not only influenced the reform agenda of Albanian governments since 2003, but it has also pushed reform in public higher education institutions. The law of higher education in 2007 which introduced the Bologna system in the Albanian higher education was used by the government to drastically change the landscape of higher education. The Bologna process legitimized the expansion of higher education, it helped the government to initiate the reform of the curricula and enforce transparency. Evidence shows that the Bologna process has been instrumentalized to legitimize and further reforms and changes in higher education policies also in other European countries, especially concerning restructuring and homogenization of the system, or ensuring transparency in the use of public money (de Wit, 2007; Gornitzka, 2006; Vukasovic, 2014).

This articles aims to provide an analysis of the process of harmonization of the Albanian Higher Education with the standards and practices of other EU member states, by focusing on the strategies and policies adopted by the state, institutions of higher education and by other actors involved. Our argument is that despite the political rhetoric, the higher education system in Albania has displayed many problems with respect to the Bologna Process, having to do with the implementation of the structural reforms of Bologna context, enhancement of students' learning, their mobility and the orientation of the higher education towards the business and the work market 
etc. The method of our investigation is analysis of the law and policy documents, as well as comparing data on Albanian higher education, which is provided by government and nongovernment agencies, with data of several countries in the European Union. The paper is divided in two main parts, besides the introduction and conclusions. The following section provides a short introduction to the most important policy initiatives for the implementation of the Bologna process. In the second section we will evaluate and analyze how Albanian higher education system has evolved within the framework of this process.

\section{Policy Initiative and Strategies for the Implementation of the Bologna Process}

The two main policy instruments for the implementation of the Bologna process have been the National Strategy of Higher Education 2008-2013 (Keshilli i Ministrave [Council of Ministers], 2008) and the law on higher education ("Ligji per Arsimin e Lartë [Law on the Higher Education in the Republic of Albania]," 2007). Other important regulations within the framework of Bologna process have been the national quality framework (2010), and guidelines and standards for the quality assurance in Albania (2004 and 2012). There were some amendments to the law of higher education in 1999 and 2006 to accommodate some of the changes initiated with the Bologna process, but only the law of 2007 was a comprehensive approach to the whole process.

Liberalization of access in higher education, which has resulted in an increase in number of university students, has also been an important aspect of the reform. Government policies were then oriented towards the expansion of the capacity of public higher education institutions. The government established new institutions and public universities opened up campuses in some remote areas. The research institutes were integrated at public. The government introduced quota for the social category of families that were politically persecuted during communism and were deprived of the right to enter the university. Affirmative action were also applied for Roma students and students with special needs.

Changes in the law of higher education also allowed for a diverse system in terms of types of institution and forms of ownership and funding. In Albania there are currently five types of institutions, universities, academies, professional colleges, schools of higher learning and interuniversity centers. The law of higher education also created a broad and encouraging legal framework for the functioning of private higher education institutions in Albania. As of 2014 there were 13 public higher education institutions (12 university and one academy), one inter -university centre and 26 private higher education institution (five universities, two professional colleges and the rest are schools of higher learning). In 2015 the government approved the new law of higher education stipulating that the schools of higher learning will be labelled "university colleges", maintaining the general characteristics of the system.

The government established the quality assurance agency in 1999, whereby the first approach to quality assurance was to evaluate the programs, and then in 2007 it changed to include both programs and institutions. Much emphasis is given to the external quality assurance, hence the agency operates based on a set of external standards and procedures. Moreover, accountability and the evaluation of the public universities is measured according to the compatibility of their activities with the legislation in force. The Albanian government has consistently confirmed the importance of the European cooperation in quality assurance but much of the system has been confusing, as in other European countries (Ursin, Huusko, Aittola, Kiviniemi \& Muhonen, 2008).

\section{Benefits and Challenges in Implementing the Bologna Process}

In this section we examine the most important issues the system is confronting in terms of the successful implementation of Bologna process. These are the following:

\subsection{Expansion and massification}

Higher education system in Albania was transformed through Bologna process. The most 
noticeable changes were liberalization, massification and the increase of higher education providers. In 1990 Albania had only 14,000 students and a limited number of higher education institutions (HEls). By 2013 the number of enrolled students increased more than tenfold. The most dramatic change in the "liberalization" of higher education occurred after 2005. The capacity of university admission increased from 52,000 student in 2005 to 165,000 students in 2013 (Report of Ministry of Education and Science, 2013). The participation of the private sector in the higher education system after the year 2000 brought a new management experience that did not previously exist in the country, which had their impact in the regulation process of higher education and in the management of the public institutions of higher education.

The number of students in the period of 2003-2013 has increased in average by $13 \%$ every year, while the increase from 1994 to 2002 had been only 6\% on average (INSTAT, 2014). Gross enrollment ratio (GER) increased almost three-fold, from $15.8 \%$ to $54.8 \%$, approaching the average GER of OECD countries. The main public universities established campuses in other cities of Albania, and the number of private of HEls increased dramatically, from five institutions in 2005 to 44 institutions by 2013. The number of academic personnel grew as well. By 2013 the number of fulltime equivalent faculty (FTE) at public universities went up to 4075 from 2552 in 2004, and the number of adjunct professors grew by almost 30\% (data calcuated by the authors based on the most recent updates and those published by Ministry of Education and Sports, 2011). Considering the social dimension of the Bologna process, the massification has also benefited the marginalized groups of the Albanian society. The gender balance in Albania is in favor of women (56\%). Women are in majority in social science and humanities, but make only $36 \%$ of graduate students in the field of engineering (Ministry of Education and Sports, 2011). The government offers specific student quotas targeting the marginalized groups: Roma students, students with disability and orphans, and both the local and central government offer scholarship for students from low socialeconomic status.

\subsection{Completion and employability}

An obvious effect of the Bologna process was also an increase in completion rates, which up to 2004 had been very low in comparison to Western Balkan countries. Now the graduation rates are estimated at about 35-36\%, a double increase since 2004, but still low in comparison to other EU countries, which have rates close to $50 \%$ (see Table 1). Higher education attainment among the 2534 year olds is still low, less than $20 \%$ in Albania (European Commission, 2015).

The massification brought with it the concern for quality, especially as an increased number of graduates are facing difficulties in finding employment. The percentage of unemployed university graduates according to Institute of Statistics (2015) has increased from three percent in 2000, to six percent in 2014. Both the issue of education attainment and that of employability are considered to be very important indicators of the quality of higher education output, as endorsed by the Ministers responsible for higher education in the Bucharest Communiqué of 2012.

\subsection{Degree structure}

The entry of Albania in the Bologna process in 2003, led to a structural reform at all levels of higher education. University study programs went through a re-organization in terms of content and structure in accordance with Bologna standards. Today higher education institution offer a total of 1560 study programs, from which 700 are supplied by public institutions (Gjoncaj, 2014, p. 13). The system offers 582 Bachelor program, 850 Master programs and 128 programs of the third cycle. Higher education institution have the right to offer professional non-university study program, after high school, not less than 120 credits and timeframe not less than 2 academic year. There is a possibility to transfer the credits in the first university cycle, based on the requirement of HEls.

Now the system in Albania has been formally structured to fit that of the Bologna Declaration the three cycle degrees. By 2012 more than $90 \%$ of students are enrolled in programs following the Bologna three-cycle structure and more than $95 \%$ of the study programs had a workload of 180 ECTS (European Commission, 2015). However, the law of higher education was adapted to take 
into account some of the traditional characteristics of the previous system, so integrated programs leading to regulated professions of health sciences still exist. For instance, a second type of master was introduced in 2007, called the master of second level, without clear definition and differentiation whether that was an academic consecutive program or continuing education. A report on the situation of the legal training in Albania revealed that students graduating from the first cycle had difficulties finding employment as their training was not sufficient and employers not knowledgeable of the system (Albanian Parliament, 2015). The report, one of the few qualitative evaluation on the quality of curriculum in higher education, further stated that the content of the syllabus were not on par with the expected standards: lack of practical relevance, there are is no core curricula for legal training, some of the programs still contain irrelevant subjects (physical training) etc. In another study mandated by the Ministry of Education and conducted by a consulting group, the consultants found that some of the old 4-year programs were 'compressed' into three year programs (Ministry of Education and Sports, 2010). The Dublin level descriptors were ignored by almost all universities. Although the National Qualification Framework was approved in 2010, it has not been fully implemented. Not all universities deliver syllabuses to the students, nor including learning outcomes is a usual practice.

Short-cycle programs are part of higher education institutions, but the number of short-cycle programs has decreased since 2013, as the number of students enrolled, especially at the University of Durres which provides the majority of these type of programs. There are no statistics of how many students transfer from short-cycle to the first cycle program, however students may transfer about 60 ECTS and the access is limited (see also European Commission, 2015). In the academic year of 2015-16 the percentage of first year students enrolled at public universities in short-cycle programs will be $2 \%$ out of 22,000 students - in three public universities and 12 study programs (Council of Ministers, 2015). Hence, university education prevails over professional education. Professional non-university education has insignificant role in national level, as referring to number and types of study programs (less than $1 \%$ of the total programs) and in the number of student in this system (Gjoncaj, 2014, p. 17).

The share of doctoral candidates in the total number of students was less than two percent in 2012 (European Commission, 2012). There has been some publicly expressed concern from the government (Hoti, 2014) related to the quality of doctoral programs in Albania and the ethical behavior of students and academics, so in 2014 the government decided to halt enrollment in public universities for Ph.D. until the new reform was to take place.

\subsection{Quality assurance}

According to a study on the higher education systems of Western Balkan countries from University of Ljubljana and Centre for Educational Policy Studies, the overall impression of the faculty, also for Albania, is that the Bologna process has not contributed to the quality (Zgaga et al., 2013). In Albania the respondents in this study differed whether they were from regional universities, whose attitude were positive, or from the capital city, whose attitude were more negative toward the Bologna process. The system of quality assurance has been provisioned by law since 1999, but the formal requirements were not sufficiently consolidated into practice. According to a government report on higher education, the external quality assurance system, the accreditation agency, although established in 2001, it was ignored by the public HEls and was under extreme pressure by the private providers (Gjoncaj, 2014). In 2014 the government of Albania revoked the license of 18 providers for non-compliance, and suspended the license of another 13 institutions, although the majority of this institutions had some sort of accreditation. However, the Public Agency for the Accreditation of Higher Education (APAAL in Albanian) and the Accreditation Council as its decision-making body, has been relatively transparent in its procedures, conform the standards of European Association for Quality Assurance (ENQA). For instance, the agency has published the decisions of the accreditation council and recently (since 2012) has started to make public the evaluation reports of its experts. It has not published negative evaluation because there are none.

The agency does claim to follow the Standards and Guidelines for Quality Assurance in the European Higher Education Area, which were endorsed by the Communiqué. However, the agency 
is still not registered on European Quality Assurance Register for Higher Education (EQAR). The agency has not lacked aspirations, but the main issue has been its lack of autonomy from the government.

Internal quality assurance have also been required by the law, but institutions have been very slow in establishing these systems and consolidating them. The government drafts and approves in details the legislation on the functioning, institutional organisation, quality assurance and monitors their efficiency. The decision-making process is relatively centralized, because the government regulates the financial sphere, whereas universities are autonomous in respect to administration, promotion of staff and the institutional organization. The monitoring of the activity of the institutions of higher education is done by inspection and bureaucratic formalities.

\subsection{Lifelong learning}

Albania also lags behind other countries in providing lifelong learning opportunities (European Commission, 2015). Some public institutions (e.g. University of Tirana) or private providers (e.g. Catholic University) do offer formal training or non-formal courses open to all, like summer schools or in the field of accounting and health administration (see also Chapter 26 of the Albanian Progress Report 2012 to the European Commission). Lifelong learning activities are mostly financed through private contributions. Even in the public sector part-time students have higher tuition fees than full-time students. With the recent government intervention because of quality issues with these type of programs, the number of part-time students has been drastically reduced, and there has been two years that no student quotas have been approved for the first cycle programs. In 2013 part-time students comprised $21.4 \%$ of the total student body. However, the majority of master programs are organized as part-time studies.

\subsection{Internationalization and mobility}

The main goals of the Bologna Process underline the international aspects of higher education processes and structures. The mobility of staff and students is one of the core elements of the process, developing international cooperation between individuals and institutions, enhancing the quality of higher education and research, and creating opportunities for personal growth (London Communiqué, 2007).

Although the number of students studying abroad has increased by six-fold since 1999 and Albania is the leading country in the Western Balkan in terms of absolute numbers of students studying abroad, the mobility through European programs has not been very successful. It is estimated that since 1999 about 25,000 Albanian citizens have studied abroad (UNESCO, 2015; see also Figure 3), but only 132 Master students had taken advantage of the Erasmus Mundus mobility program.

However, Albania has profited from the internationalization agenda of the European Union, which primary instruments have been mobility programs of academic staff and students, as well as the internationalization of the substance of teaching, learning, and research (Kehm \& Teichler, 2007). It first participated in 1992 with the EUREKA program which promoted market-oriented solutions and innovation by assisting small-medium enterprises and universities, and later with Socrates (Leon \& Reid, 2010).

Although the national level has an important influence on the international dimension in higher education - through policy, funding, programs, and regulatory frameworks - it is usually at the individual and institutional level where the real process of internationalization is taking place (Knight, 2004). In this perspective Albanian higher education institutions are lagging behind their counterparts in Eastern European countries both in staff mobility and research (see European Commission, 2015). For instance, in the period of 2004-2014 it had 132 students in the master programs through Erasmus Mundus, nine in doctoral studies and only three scholars, while Serbia had 362 students in master programs, 38 in joint doctorates and 14 scholars (EACEA, 2015). In 2010 Albania's contribution in Framework Programs, FP6, was small but its number of participation in the program was also small, 35 projects, with an average of seven a year; in comparison to 42, 
with an average of eight projects per year, for Bosnia and Herzegovina (Leon \& Reid, 2010).

There are very few joint programs with universities from abroad, currently only with Italy. The number of Tempus projects where Albanian universities are either project coordinators or collaborators was also small in comparison to other Western Balkan countries like Serbia (WEBINCO.net, 2011). Therefore, we believe that there is some room for mobility of students and academic staff through joint programs with European universities, which, on one hand will raise the scientific quality of national programs and make Albanian diplomas compatible with the standards of European Higher Education Area and, on the other hand, will contribute to brain gain.

\section{Conclusions}

The objective of this study was to outline and analyze the political processes and institutional measures which preceded, influenced and followed the implementation of the Bologna process in Albania. As most Western Balkan countries, Albania is facing various challenges, in terms of the political transformation, economic restructuring and joining the global economy. By presenting and analyzing the policy instruments applied for the implementation of the Bologna process, we have examined some of the emerging issues as Albania tries to catch up with the educational systems of Western democracies.

In the framework of the Bologna Process, higher education policies in Albania may be understood in terms of policy trade-offs. This analytical approach requires further elaboration which we will pursue in our coming publications. Shortly we conclude that the Albanian government has consistently prioritized short-term policy goals that have brought immediate and tangible changes. The government has favored massification instead of quality and reliable structures of quality control. It had aimed to increase the number of faculty and expand the system versus ensuring rigorous promotion and recruitment procedures. Or the government has encouraged the development of private education, in order to increase access and competition versus trying to ensure quality and compliance from private for-profit providers, which would normally operate under an economic rationale. Further, rather than enforcing the quality assurance instruments in place, the government has yielded to the interests of the academic community.

In 2012-13 the government prepared another reform of higher education, which was brought to a halt because the government could not bear the immense political costs it entailed and, it was facing the resistance of public universities. The reform sought to change the funding in favor of a more participative funding scheme and restructure the governance system of higher education institutions. The new government of 2013 has since claimed to initiate a reform to confront some of the challenges with a similar approach (increase tuition fees and change the management model of public universities). A new law on higher education was passed on July 2015. It remains to be seen whether the law will positively affect the implementation of the Bologna process in Albania.

\section{References}

Albanian Parliament. (2015a). Analize e Sistemit te Drejtesise ne Shqiperi [Analysis of Judicial System in Albania]. Tirana: Albanian Parliament - Special Parlamentary Commission for the Reform of the Judiciary.

Albanian Parliament. (2015c). Legjislatura VIII - Procesverbal - Seanca e Ditës së Marte, 21 Korrik 2015 [Protocol of the parliamentary session. Tuesday 21 July 2015]. Tirana: Albanian Parliament,.

Council of Ministers. (2015, 22 July). Vendim për kuotat e pranimit në Institucionet Publike të Arsimit të Lartë, në programet e studimeve të ciklit të parë [Decree on student quota for public higher education institutions in the first cycle program ...]. Retrieved 22 July, 2015, from http://www.arsimi.gov.al/al/newsroom/v-k$\mathrm{m} /$ vendim-per-kuotat-e-pranimit-ne-institucionet-publike-te-arsimit-te-larte-ne-programet-e-studimeve-teciklit-te-pare-ne-programet-e-studimeve-jouniversitare-profesionale-dhe-ne-programet-e-integruara-testudimeve-te-ciklit-te-dyte-me-kohe-te-plote-si-edhe-tarifat-e-shkollimit-per-vitin-akademik-2015-2016

De Wit, H. (2007). European Integration in Higher Education: The Bologna Process Towards a European Higher Education Area. In J. J. F. Forest \& P. G. Altbach (Eds.), International Handbook of Higher Education (Vol. 18, pp. 461-482). Dordrecht: Springer.

EACEA. (2015). Erasmus Mundus Statistics: 2013 Scholarship statistics by nationality. from http://eacea.ec.europa.eu/erasmus_mundus/results_compendia/statistics_en.php

European Commission, E., Eurydice,. (2015). The European Higher Education Area in 2015: Bologna Process 
Implementation Report. Luxembourg: Publications office of the European Union.

Gjoncaj, A. (2014, 28 April). Komisioni për Arsimin e Lartë dhe Kërkimin Shkencor [Commission for Higher Education and Research]. Retrieved from http://www.kalksh.org/

Gornitzka, Â. (2006). What is the use of Bologna in national reform? Creating the European Area of Higher Education (pp. 19-41): Springer.

Hoti, B. (2014, 9 February). Rama: Arsimi, fund pazareve te diplomave [Rama: Education, end to degree purchase]. Retrieved 29 June, 2015, from http://gazeta-shqip.com/lajme/2014/02/09/rama-arsimi-fundpazareve-te-diplomave/

INSTAT. (2014). Arsimi [Education]. Retrieved 5 May 2014, from Instituti i Statistikave http://www.instat.gov.al/al/themes/arsimi.aspx?tab=tabs-5

Kehm, B. M., \& Teichler, U. (2007). Research on internationalisation in higher education. Journal of Studies in International Education, 11(3-4), 260-273.

Keshilli i Ministrave [Council of Ministers]. (2008). Për Miratimin e Strategjisë Kombëtare për Arsimin e Lartë, 2008-2013 [On the Approval of the National Strategy of Higher Education 2008-13]. Tirana.

Leon, R., \& Reid, L. A. (2010). Participation of South-East European countries in the competitive funding programs for research in the European Commission: Technopolis Group for UNESCO.

Ligji per Arsimin e Lartë [Law on the Higher Education in the Republic of Albania], www.ligjet.org, Pub. L. No. 9741 (Qendra e Botimeve Zyrtare 200721 May).

Ministry of Education and Sports. (2010). Development of an Action Plan for the Implementation of the Bologna Process: Preparation of Higher Education Standards per Teaching Cycles According to the Demands of the Bolonga Process: DAAD \& Finisht Consulting Group.

Ministry of Education and Sports. (2011). Vjetari Statistikor 2009-10 [Annual Statistics Book 2009-2010].

UNESCO. (2015). Outbound internationally mobile students by host region. Retrieved from: http://data.uis.unesco.org/

Ursin, J., Huusko, M., Aittola, H., Kiviniemi, U., \& Muhonen, R. (2008). Evaluation and quality assurance in Finnish and Italian universities in the Bologna process. Quality in Higher Education, 14(2), 109-120.

Vukasovic, M. (2014). When and How Does Europe Matter[quest] Higher Education Policy Change in Croatia, Serbia and Slovenia. High Educ Policy, 27(3), 403-423. doi: 10.1057/hep.2013.36

WEB-INCO.net. (2011). TEMPUS IV Statistics- Western Balkan Countries. Retrieved 8 July, 2015, from http://wbc-inco.net/object/document/7418

Zgaga, P., Klemenčič, M., Komljenovič, J., Miklavič, K., Repac, I., \& Jakačić, V. (2013). Higher education in the Western Balkans: Reforms, developments, trends. Center for Education Policy Studies, Ljubljana. 